\title{
Upaya Peningkatan Hasil Belajar Siswa Mata Pelajaran Fiqih Materi Pembelajaran Haji Dan Umrah
} Melalui Penerapan Metode Advokasi

\author{
Suhartono ${ }^{1 *}$, Rosi Patma \\ ${ }^{12}$ STKIP Nurul Huda OKU Timur \\ *suhartono@stkipnurulhuda.ac.id
}

\begin{abstract}
Abstrak
Tujuan penelitian ini untuk mengetahui ada tidaknya peningkatan hasil belajar mata pelajaran Fiqih melalui penerapan metode Advokasi. Penelitian menggunakan desain penelitian tindakan kelas. Prosedur penelitian melalui perencanaan, pelaksanaan, observasi dan refleksi. Subjek penelitian adalah siswa kelas VIII-2 MTs Darul Ulum Kecamatan Bumi Agung Kabupaten Way Kanan berjumlah 22 siswa. Teknik pengumpulan data menggunakan observasi dan tes, teknik analisa data menggunakan teknik holberman yaitu reduksi, penyajian dan penarikan kesimpulan.

Kesimpulan penelitian ini, pertama hasil belajar sebelum penerapan metode Advokasi adalah sangat rendah yaitu dari 22 siswa terdapat 3 siswa atau 13,64\%, siswa tidak mencapai ketuntasan sebanyak 19 orang atau $86,38 \%$. Kedua hasil belajar setelah penerapan metode Advokasi termasuk kategori tinggi dengan indikator $100 \%$ siswa dapat mencapai ketuntasan setelah tindakan siklus 3. Ketiga Penerapan metode Advokasi dapat meningkatkan hasil belajar dengan indikator aktivitas guru dalam pembelajaran termasuk kategori baik $95 \%$ pada siklus 3 semula $72,50 \%$ pada siklus 2 dan $45 \%$ pada siklus 1, dan 32,50\% pada prasiklus, aktivitas siswa dalam pembelajaran masuk kategori baik yaitu mencapai $93,56 \%$ pada siklus 3 dimana semula $67,42 \%$ pada siklus 2, 46,97 pada siklus 1 dan $28,40 \%$ pada prasiklus serta belajar siswa mencapai $100 \%$ dimana semula $13,64 \%$ pada prasiklus, $40,91 \%$ pada siklus $1,72,73 \%$ pada siklus 2 .
\end{abstract}

Kata kunci: Metode Advokasi, Hasil Belajar Fiqih.

\section{PENDAHULUAN}

Islam sebagai suatu bentuk ajaran yang kaffah memberikan perhatian cukup besar dalam bidang pendidikan. Pendidikan dilaksanakan agar tercipta perubahan yang diharapkan dalam seluruh perubahan pada dunia kehidupan manusia. Pendidikan dilaksanakan agar manusia dapat mengenal Tuhannya dan agar manusia dapat membangun sebuah bangsa yang mulia yang tegak sebagai khilafah ar rasyidah di dunia dan mendidik jiwa kemanusiaan dalam seluruh aspek, sehingga terbangun integralitas manusia dalam aspek pribadi, spiritual, sosial dan peradaban. Tujuan sebagaimana tersebut diupayakan untuk terwujud melalui pelaksanaan Pendidikan Agama Islam.

Berkaitan dengan Pendidikan Agama Islam, Daradjat (2008:86) menjelaskan sebagai berikut: Pendidikan Agama Islam adalah pendidikan dengan melalui ajaran-ajaran agama Islam yaitu berupa bimbingan dan asuhan terhadap anak didik agar nantinya setelah selesai dari pendidikan ia dapat memahami, menghayati, dan mengamalkan ajaran-ajaran agama Islam yang telah diyakininya secara menyeluruh, serta menjadikan ajaran agama Islam sebagai suatu pandangan hidupnya demi keselamatan serta kesejahteraan hidup di dunia maupun di akhirat kelak.

Pada implementasinya Pendidikan Agama Islam di lembaga-lembaga pendidikan keagamaan seperti di Madrasah Tsanawiyah dibagi menjadi sub-sub mata pelajaran secara khusus yaitu AlQur'an Hadis, Fiqih, Aqidah Akhlak dan Sejarah Kebudayaan Islam. Fiqih secara umum merupakan 
salah satu bidang studi Islam yang banyak membahas tentang hukum yang mengatur pola hubungan manusia dengan Tuhannya, antara manusia dengan manusia, dan manusia dengan lingkungannya. Melalui bidang studi Fiqih ini diharapkan siswa tidak lepas dari jangkauan norma-norma agama dan menjalankan aturan syariat Islam.

Tujuan pembelajaran Fiqih dijadikan sebagai dasar dalam pelaksanaan seluruh aktivitas pembelajaran Fiqih yang dilaksanakan mulai tingkat sekolah dasar hingga di tingkat menengah atas. Ketercapaian tujuan pembelajaran Fiqih sebagaimana pada pembelajaran lain sering disebut dengan hasil belajar. Berkaitan dengan hasil belajar, Thobroni (2011:22) mengatakan "Hasil belajar adalah pola-pola perbuatan, nilai-nilai, pengertian-pengertian, sikap-sikap, apresiasi dan keterampilan yang diperoleh individu setelah kegiatan belajar".

Pencapaian hasil belajar Fiqih dipengaruhi oleh beberapa faktor sebagaimana faktor yang mempengaruhi belajar. Berkaitan dengan faktor yang mempengaruhi belajar, Slameto (2010:54) menjelaskan bahwa faktor yang mempengaruhi belajar dapat digolongkan menjadi dua golongan yaitu faktor intern dan faktor ekstern. Faktor intern adalah faktor dalam diri individu sedang belajar, sedangkan faktor ekstern adalah faktor di luar individu seperti penggunaan pendekatan maupun metode pembelajaran secara tepat.

Berdasarkan penjelasan tersebut diketahui bahwa metode pembelajaran merupakan salah satu faktor yang mempengaruhi belajar siswa yang akan berimplikasi pada tingkat ketercapaian hasil belajar. Metode pembelajaran sebagai salah satu faktor penentu keberhasilan belajar siswa kurang mendapatkan perhatian dari para guru. Umumnya guru menyampaikan materi pembelajaran hanya sekedar kejar target kurikulum. Hal tersebut sebagaimana terjadi pada pembelajaran Fiqih di kelas VIII-2 MTs Darul Ulum Kecamatan Bumi Agung Kabupaten Way Kanan. Berdasarkan hasil observasi pendahuluan diketahui bahwa pembelajaran Fiqih di kelas VIII-2 MTs Darul Ulum dilakukan dengan cara-cara tradisional yaitu dengan sistem komunikasi satu arah dari guru kepada siswa melalui metode ceramah. Selama kegiatan pembelajaran siswa bersikap pasif mendengarkan penjelasan guru tanpa banyak mendapatkan waktu untuk mengemukakan pendapat maupun pemahaman terhadap materi pembelajaran.

Keadaan pembelajaran Fiqih di kelas VIII-2 MTs Darul Ulum sebagaimana tersebut mengakibatkan pemahaman siswa terbatas pada apa yang disampaikan guru melalui ceramah dan berimplikasi pada ketuntasan hasil belajar siswa menjadi rendah. Hal tersebut dibuktikan dari hasil dokumentasi nilai midle semester ganjil tahun pelajaran 2015/2016 yang menunjukkan dari 22 siswa hanya terdapat 3 siswa $(13,64 \%)$ yang mencapai ketuntasan dengan memperoleh nilai $\geq 70$, sedangkan 19 siswa $(86,38 \%)$ belum mencapai ketuntasan dengan memperoleh nilai $<70$.

Uraian keadaan pembelajaran Fiqih di kelas VIII-2 MTs Darul Ulum sebagaimana tersebut menunjukkan permasalahan dalam kegiatan pembelajaran. Setelah dilakukan identifikasi lebih lanjut diketahui bahwa penyebab hasil belajar Fiqih siswa kelas VIII-2 MTs Darul Ulum yang rendah adalah karena sistem pembelajaran yang berpusat pada guru melalui penerapan metode ceramah. Oleh karena itu, perlu diadakan perubahan metode pembelajaran Fiqih di kelas VIII-2 MTs Darul Ulum yang dalam hal ini melalui penerapan metode Advokasi. 
Metode pembelajaran Advokasi merupakan pembelajaran yang berpusat pada siswa (student-centered advocacy learning) sering diidentikkan dengan proses debat. Utsman (2011:46) mengemukakan, "Metode pembelajaran Advokasi adalah metode pembelajaran yang mana mengajak siswa aktif dalam kegiatan pembelajaran sehingga diharapkan dengan menggunakan metode Advokasi dapat meningkatkan hasil belajar siswa". Pembelajaran Advokasi dipandang sebagai suatu pendekatan alternatif terhadap pengajaran didaktis di dalam kelas yang memberikan kesempatan kepada siswa untuk mempelajari isu-isu sosial dan personal melalui keterlibatan langsung dan partisipasi pribadi. Metode pembelajaran Advokasi menuntut para siswa terfokus pada topik yang telah ditentukan sebelumnya dan mengajukan pendapat yang bertalian dengan topik pembelajaran.

Menurut Huda (2013:117), metode pembelajaran Advokasi merupakan metode pembelajaran alternatif untuk meningkatkan proses belajar siswa yang memberikan kesempatan kepada siswa utuk menjadi Advokat dari suatu pendapat tertentu yang bertalian dengan topik yang tersedia. Siswa menggunakan keterampilan riset, keterampilan analisis, dan keterampilan berbicara dan juga mendengar, sebagaimana mereka berpartisipasi dalam kelas pengalaman Advokasi. Siswa pada pembelajaran Advokasi dihadapkan dengan isu-isu kontroversial dan harus mengembangkan suatu kasus untuk mendukung pendapat mereka di dalam perangkat untuk tujuan-tujuan khusus. Hal ini menunjukkan bahwa metode pembelajaran Advokasi adalah metode pembelajaran yang mengajak siswa turut aktif dalam kegiatan pembelajaran. sehingga diharapkan dengan menggunakan metode Advokasi dapat meningkatkan hasil belajar siswa.

Berdasarkan penjelasan tersebut metode Advokasi muncul asumsi bahwa metode Advokasi akan efektif apabila diterapkan pada pembelajaran Fiqih. Hal tersebut karena materi pembelajaran Fiqih berisi masalah-masalah hukum yang sangat kompleks dan menimbulkan banyak penafsiran. Melalui penerapan metode Advokasi siswa dilatih untuk mencari informasi tentang hukum suatu masalah dan memperdebatkan informasi yang telah diperoleh sehingga akan dapat memperdalam pemahamannya terhadap materi pembelajaran Fiqih. Dengan demikian, pemahaman siswa terhadap materi pembelajaran Fiqih tidak hanya terbatas pada apa yang disampaikan oleh guru atau pada apa yang tertera dalam buku paket, namun siswa akan memiliki kemampuan untuk memecahkan masalah-masalah ikhtilafiyah pada materi Fiqih.

\section{LANDASAN TEORI}

\section{Pengertian Metode Advokasi}

Metode pembelajaran Advokasi merupakan pembelajaran yang berpusat pada siswa (student-centered advocacy learning) yang sering diidentikkan dengan proses debat. Pembelajaran advokasi dipandang sebagai suatu pendekatan alternatif terhadap pengajaran didaktis di dalam kelas yang memberikan kesempatan kepada siswa untuk mempelajari materi pembelajaran melalui keterlibatan langsung dan partisipasi pribadi. Metode pembelajaran Advokasi menuntut para siswa terfokus pada topik yang telah ditentukan sebelumnya dan mengajukan pendapat yang bertalian dengan topik tersebut (Wena, 2013:137). 
Berdasarkan pengertian metode Advokasi diketahui bahwa metode Advokasi adalah metode pembelajaran yang berpusat pada siswa (student centered) sering diidentikkan dengan proses debat (advocacy learning). Advocacy learning dipandang sebagai suatu pendekatan alternatif terhadap pengajaran di dalam kelas yang memberikan kesempatan kepada siswa untuk mempelajari isu-isu sosial dan personal yang berarti melalui keterlibatan langsung dan partisipasi pribadi. Metode Advokasi menuntut para siswa berfokus pada topik yang telah ditentukan sebelumnya dan mengajukan pendapat yang berkaitan dengan topik tersebut.

\section{Langkah-langkah Penerapan Metode Advokasi}

Berdasarkan adanya regu pendukung dan penentang pada penerapan metode pembelajaran Advokasi, Hamalik (2010:117) menyusun langkah-langkah pembelajaran menggunakan metode Advokasi sebagai berikut:

1. Memberikan apersepsi dengan cara yang menarik.

2. Menjelaskan prosedur kegiatan pembelajaran yang akan dilaksanakan.

3. Membagikan ringkasan materi sebagai sumber informasi awal kepada siswa.

4. Memberikan penjelasan tentang materi pembelajaran sebagaimana terdapat pada ringkasan materi.

5. Memberikan kesempatan kepada siswa untuk menanyakan materi yang belum dipahami dalam ringkasan materi pembelajaran.

6. Memilih suatu topik debat berdasarkan pertimbangan aspek kebermaknaannya, tingkatan siswa, relevansinya dengan kurikulum, dan minat para siswa.

7. Memilih dua regu debat dengan menunjuk ketua regu, notulen serta juru bicara.

8. Menugaskan setiap regu mencari informasi dari berbagai sumber tentang topik debat yang telah diberikan.

9. Menugaskan setiap regu untuk mendiskusikan informasi yang diperoleh sebagai bentuk persiapan debat.

10. Menyediakan petunjuk dan asistensi kepada siswa untuk membantuk menyiapkan debat.

11. Setelah semua siswa mendengarkan argumen pembuka dari masing-masing regu perintahkan setiap kelompok untuk menyusun strategi dalam rangka mematahkan argumen pembuka dari pihak lawan.

12. Perintahkan para juru bicara yang duduk berhadap-hadapan untuk memberikan argumentasi tandingan. Pada saat debat, anggota kelompok dapat membantu juru bicara dalam memperkuat argumentasi yang diajukan.

13. Anjurkan peserta lain untuk memberikan catatan yang memuat argumen tandingan atau bantahan kepada pendebat mereka serta anjurkan siswa untuk memberi tepuk tangan atas argumen yang disampaikan oleh perwakilan tim debat mereka.

14. Pada saat debat berakhir, usahakan agar tidak menyebut pemenangnya, dan perintahkan siswa untuk kembali berkumpul membentuk satu lingkaran. Pastikan untuk mengumpulkan siswa dengan duduk bersebelahan dengan siswa yang berasal dari pihak lawan debatnya.

15. Berilah kesimpulan dengan mengambil pendapat setiap kelompok yang telah diperdebatkan.

16. Berilah evaluasi untuk mengetahui tingkat pemahaman siswa terhadap materi pembelajaran.

17. Tutup kegiatan pembelajaran dengan memberikan refleksi dan penguatan.

Berdasarkan langkah-langkah pelaksanaan metode Advokasi diketahui bahwa siswa pada penerapan metode Advokasi dibagi menjadi dua regu yakni regu yang mendukung suatu kebijakan (affirmative) dan regu lawannya ialah regu oposisi (negatif). Masing-masing regu menyampaikan pendapatnya disertai dengan argumentasi, bukti, dan berbagai landasan, serta menunjukkan bahwa pandangan pihak lawannya memiliki kelemahan, sedangkan pendapat regunya sendiri adalah yang terbaik. Tiap regu berupaya menyakinkan kepada pengamat, bahwa pandangan/pendapat regunya 
paling baik dan harus diterima. Jadi, tiap regu bertanggung jawab secara menyeluruh atas posisi regunya, disamping adanya tanggungjawab setiap anggota regu.

\subsection{Hasil Belajar Fiqih}

Hasil belajar merupakan bentuk perubahan yang dialami oleh seseorang yang mencakup aspek kognitif, afektif, dan psikomotorik. Hasil belajar dapat diklasifikasikan menjadi tiga yaitu hasil belajar kognitif, afektif dan psikomotorik. Masing-masing jenis hasil belajar dapat diuraikan sebagai berikut:

\section{Hasil Belajar Kognitif}

Hasil belajar kognitif merupakan hasil belajar yang mencakup kegiatan mental atau kerja otak. Djamaluddin (2009:58) mengemukakan, "Segala upaya yang menyangkut aktivitas otak adalah termasuk dalam ranah kognitif". Penjelasan tersebut menunjukkan bahwa hasil belajar kognitif berhubungan dengan kemampuan berfikir termasuk didalamnya kemampuan menghafal, memahami, mengaplikasi, menganalisis, mensintesis, dan kemampuan mengevaluasi. Hasil belajar kognitif meliputi enam aspek atau jenjang proses berfikir mulai dari jenjang terendah sampai dengan jenjang yang paling tinggi. Keenam jenjang atau aspek hasil belajar kognitif dapat diuraikan sebagai berikut:
a. Pengetahuan (Knowledge)
b. Pemahaman (Comprehension)
c. Penerapan (Application)
d. Analisis (Analysis)
e. Sintesis (Syntesis)
f. Evaluasi (Evaluation)

Berdasarkan enam jenjang hasil belajar kognitif diketahui bahwa tujuan aspek kognitif berorientasi pada kemampuan berfikir yang mencakup kemampuan intelektual yang lebih sederhana yaitu mengingat sampai pada kemampuan memecahkan masalah yang menuntut siswa untuk menghubungkan dan menggabungkan beberapa ide, gagasan, metode atau prosedur yang dipelajari untuk memecahkan masalah. Dengan demikian aspek kognitif merupakan subtaksonomi yang mengungkapkan tentang kegiatan mental yang sering berawal dari tingkat pengetahuan sampai ke tingkat yang paling tinggi yaitu evaluasi.

\section{Hasil Belajar Afektif}

Selain ranah kognitif evaluasi pembelajaran juga dilakukan pada aspek afektif sehingga terdapat jenis hasil belajar afektif. Menurut Davies (dalam Primansari, 2012:63), ranah afektif berhubungan dengan lima sikap sebagai berikut:
a. Menerima (Receiving)
b. Merespon (Responding)
c. Menilai (Valuing)
d. Mengorganisasi (Organization)
e. Karakterisasi (Characterization)

Berdasarkan penjelasan hasil belajar afektif dan jenjang afektif dapat disimpulkan bahwa hasil belajar afektif adalah hasil belajar yang berkaitan dengan sikap dan nilai. Hasil belajar afektif 
dapat berwujud perilaku yang menekankan perasaan, emosi, atau derajat tingkat penolakan atau penerimaan terhadap suatu objek.

\section{Hasil Belajar Psikomotorik}

Hasil belajar selain ranah kognitif dan afektif adalah ranah psikomotor. Menurut Davies (dalam Dimyati, 2009:207), "Hasil belajar psikomotor berhubungan dengan keterampilan motorik, manipulasi benda atau kegiatan yang memerlukan koordinasi saraf dan koordinasi badan". Sejalan dengan pendapat tersebut, Sudjana (2004:54) menjelaskan bahwa "Hasil belajar psikomotor tampak dalam bentuk keterampilan-keterampilan dan kemampuan bertindak individu". Taksonomi hasil belajar psikomotor disusun secara hierarkis dalam lima tingkatan sebagai berikut:

1. Meniru, artinya siswa dapat meniru atau mengikuti suatu perilaku yang dilihatnya.

2. Manipulasi, artinya siswa dapat melakukan sesuatu tanpa bantuan visual sebagaimana pada tingkat meniru.

3. Ketetapan gerak, artinya siswa diharapkan dapat melakukan sesuatu perilaku tanpa menggunakan contoh visual ataupun petunjuk tertulis.

4. Artikulasi, artinya siswa diharapkan dapat menunjukkan serangkaian gerakan dengan akurat, urutan yang benar, dan kecepatan yang tepat.

5. Naturalisasi, artinya siswa diharapkan melakukan gerakan tertentu secara spontan atau otomatis (Djamaluddin, 2009:65).

Pengertian dan tingkatan hasil belajar psikomotorik sebagaimana uraian di atas memberikan pemahaman hasil belajar psikomotorik tampak dalam bentuk keterampilan maupun kemampuan bertindak individu. Hasil belajar psikomotorik mengacu pada kemampuan bertindak. Hasil belajar psikomotorik ini merupakan implementasi dari berbagai konsep maupun teori yang telah dipelajari atau sebagai hasil dari pelatihan yang telah dijalani. Penjelasan tersebut memberikan pengertian bahwa hasil belajar aspek psikomotorik adalah kemampuan siswa dalam mengaplikasikan atau mempraktikkan materi pelajaran dalam kehidupan sehari-hari. Aspek psikomotorik merupakan perwujudan materi pelajaran dalam perilaku sehari-hari.

Berdasarkan klasifikasi hasil belajar sebagaimana telah diuraikan, hasil belajar dimaksud pada penelitian ini adalah hasil belajar kognitif yaitu kemampuan inteligensi siswa menyerap materi pembelajaran. Ranah belajar kognitif pada penelitian ini terdiri atas ingatan (C1), pemahaman (C2) dan penerapan (C3). Hasil belajar kognitif pada penelitian ini dibatasi pada ingatan, pemahaman serta penerapan. Hasil belajar siswa diketahui melalui instrumen tes. Tinggi rendahnya hasil belajar siswa ditentukan dari tinggi rendahnya nilai hasil tes siswa.

\section{METODOLOGI PENELITIAN}

Jenis penelitian yang digunakan pada penelitian ini adalah penelitian tindakan berupa penelitian tindakan kelas atau classroom in action research. Arikunto (2007:3) mengungkapkan, "Penelitian tindakan kelas adalah suatu pencermatan terhadap kegiatan belajar berupa sebuah tindakan, yang sengaja dimunculkan dan terjadi dalam sebuah kelas secara bersama". Sedangkan menurut Wardhani (2002:4) mengemukakan, "Penelitian tindakan kelas adalah penelitian dilakukan guru di dalam kelasnya sendiri melalui refleksi dengan tujuan memperbaiki kinerjanya sebagai guru, sehingga hasil belajar siswa menjadi meningkat". 
Penelitian dilaksanakan menggunakan desain Kurt Lewin. Muslich (2010:17) menjelaskan bahwa, "Kurt Lewin memperkenalkan konsep penelitian tindakan meliputi empat komponen yaitu perencanaan (planning), tindakan (acting), pengamatan (observing), dan refleksi (reflecting)."

Objek penelitian ini adalah proses pembelajaran Fiqih melalui penerapan metode Advokasi di kelas VIII-2 MTs Darul Ulum Kecamatan Bumi Agung Kabupaten Way Kanan. Subjek dari penelitian ini adalah siswa kelas VIII-2 MTs Darul Ulum Kecamatan Bumi Agung Kabupaten Way Kanan berjumlah 22 siswa dengan perincian 16 siswa laki-laki dan 6 siswa perempuan.

Pada penelitian ini teknik pengumpulan data yang dilakukan adalah teknik observasi dan teknik tes. Analisis data yang dilakukan meliputi analisis data hasil observasi dan analisis data hasil tes. Observasi aktivitas belajar siswa dilakukan menggunakan lembar observasi yang terdiri aspek inti kegiatan siswa pada penerapan metode Advokasi yaitu kemampuan bekerjasama, pertisipasi dan kemampuan presentasi siswa selama pembelajaran. Jika komponen-komponen observasi muncul pada deskriptor yang diberikan, maka observer diminta membubuhkan tanda cek $(\sqrt{ })$ pada kolom angka 1 sampai 4 . Selanjutnya observer memberikan skor pada masing-masing komponen yang sudah diberi tanda cek $(\sqrt{ })$. Observasi aktivitas guru digunakan untuk mengetahui efektivitas guru dalam mengelola kegiatan pembelajaran. Kegiatan observasi dilakukan menggunakan alat penilaian kinerja guru sebagaimana langkah-langkah kegiatan pembelajaran menggunakan metode advokasi yang terdiri atas 10 aspek penilaian. Observasi dilakukan dengan memberikan tanda cek $(\sqrt{ })$ pada kolom angka mulai 1 sampai 4 .

Analisis data hasil tes untuk setiap siklusnya dilakukan dengan menghitung persentase ketuntasan belajar. Ketuntasan belajar pada penelitian ini terbagi menjadi dua yaitu ketuntasan individual dan ketuntasan klasikal. Penentuan ketuntasan belajar didasarkan pada ketentuan sekolah yang bersangkutan yaitu secara individual siswa dianggap tuntas apabila memperoleh nilai $\geq 70$ dan secara klasikal ketuntasan belajar adalah $90 \%$ dari jumlah siswa seluruhnya telah memperoleh nilai 270. Pada bagian akhir setelah tindakan selesai, dilakukan perhitungan besarnya peningkatan hasil belajar siswa setiap siklus.

\section{HASIL DAN PEMBAHASAN}

Masalah diangkat dalam penelitian ini adalah rendahnya hasil belajar mata pelajaran Fiqih siswa. Setelah masalah penelitian diketahui, dilakukan analisis penyebab terjadinya masalah dan diketahui bahwa masalah muncul karena pembelajaran Fiqih hanya dilaksanakan secara verbalis. Selain itu, masalah muncul akibat kurangnya waktu bagi siswa berlatih menganalisis dan merumuskan permasalahan sehingga pengetahuan siswa hanya bersifat teoretis. Oleh karena itu, tindakan akan dilakukan dengan metode Advokasi. Secara keseluruhan hasil dari tindakan dapat dideskripsikan sebagai berikut:

1. Hasil Belajar Mata Pelajaran Fiqih Materi Pembelajaran Haji dan Umrah Siswa Sebelum Penerapan Metode Advokasi di Kelas VIII-2 MTs Darul Ulum Kecamatan Bumi Agung Kabupaten Way Kanan

Pelaksanaan tindakan prasiklus dilakukan melalui pembelajaran menggunakan rencana pelaksanaan pembelajaran yang telah disusun pada tahap perencanaan yaitu pada materi 
pembelajaran yaitu pengertian, syarat wajib, rukun, wajib, dan sunnah haji. Pembelajaran dilakukan oleh peneliti yang bertindak sebagai guru dengan dibantu kolaborator sebagai observer. Pembelajaran prasiklus dilakukan satu kali pertemuan dengan alokasi waktu 2 x 40 menit.

Prosentase aktivitas guru dalam pembelajaran prasiklus adalah rendah. Prosentase hasil observasi aktivitas guru dalam pembelajaran sebesar $32,50 \%$ berada pada interval $26-50 \%$ sehingga diinterpretasikan bahwa aktivitas guru dalam kegiatan pembelajaran prasiklus adalah rendah. Aktivitas belajar siswa kelas VIII-2 MTs Darul Ulum Kecamatan Bumi Agung adalah rendah. Prosentase aktivitas belajar siswa secara klasikal sebesar $28,41 \%$ berada pada interval 26 - $25 \%$ yang berada pada kategori rendah.

Rendahnya aktivitas guru dan siswa selama kegiatan pembelajaran berimplikasi pada rendahnya hasil belajar siswa. Berdasarkan hasil tes pada tindakan prasiklus diperoleh nilai total siswa sebesar 1110 dengan nilai rata-rata siswa hanya mencapai 50,45 , jumlah siswa mencapai KKM sebanyak 3 siswa atau 13,64\%, siswa tidak mencapai ketuntasan sebanyak 19 orang atau $86,38 \%$. Ketuntasan belajar sebesar $13,64 \%$ berada pada interval $1-25$ yang berarti ketuntasan belajar siswa adalah sangat rendah. Oleh karena itu, perlu dilaksanakan tindakan untuk memperbaiki proses serta hasil belajar siswa yang dalam hal ini melalui penerapan metode Advokasi dalam tindakan penelitian kelas.

2. Hasil Belajar Mata Pelajaran Fiqih Materi Pembelajaran Haji dan Umrah Siswa Setelah Penerapan Metode Advokasi di Kelas VIII-2 MTs Darul Ulum Kecamatan Bumi Agung Kabupaten Way Kanan

Pada setiap akhir kegiatan pembelajaran siklus dilakukan evaluasi untuk mengetahui hasil belajar mata pelajaran Fiqih siswa. Evaluasi dilaksanakan dengan memberikan soal-soal tertulis berbentuk pilihan ganda sebanyak 10 nomor. Seluruh kegiatan tes setiap siklus diikuti oleh seluruh siswa kelas VIII-2 MTs Darul Ulum Kecamatan Bumi Agung Kabupaten Way Kanan yang berjumlah 22 orang siswa.

Hasil tes mata pelajaran Fiqih siswa setelah tindakan siklus 1 adalah memperoleh nilai total 1380 dengan nilai rata-rata siswa mencapai 62,73, jumlah siswa mencapai KKM sebanyak 9 siswa atau $40,91 \%$, siswa tidak mencapai ketuntasan sebanyak 13 orang atau 59,09\%. Prosentase ketuntasan belajar siswa setelah tindakan siklus 1 sebesar 40,91\%. Ketuntasan belajar siswa diketahui bahwa hasil belajar Fiqih siswa kelas VIII-2 MTs Darul Ulum Kecamatan Bumi Agung setelah tindakan siklus 1 melalui penerapan metode Advokasi adalah rendah. Pelaksanaan tindakan siklus 1 dapat meningkatkan hasil belajar Fiqih siswa sebesar 27,27\% dari tindakan prasiklus.

Kegiatan penelitian siklus 1 ditindaklanjuti dengan melaksanakan tindakan siklus 2. Pada akhir kegiatan tindakan siklus 2 dilakukan evaluasi untuk mengetahui hasil belajar Fiqih siswa. Hasil evaluasi menunjukkan skor total yang diperoleh siswa adalah 1610 dengan nilai rata-rata siswa mencapai 73,18, jumlah siswa mencapai KKM sebanyak 16 siswa atau 72,73\%, siswa tidak mencapai ketuntasan sebanyak 6 orang atau $27,27 \%$. Prosentase ketuntasan belajar siswa pada tindakan siklus 2 sebesar $72.73 \%$. Hal tersebut menunjukkan bahwa hasil belajar mata pelajaran Fiqih siswa pada tindakan siklus 3 adalah tinggi. Meskipun telah terjadi peningkatan hasil belajar 
siswa yang signifikan, namun target penelitian sebesar 90\% dari jumlah siswa seluruhnya mencapai ketuntasan belum tercapai, sehingga penelitian harus dilanjutkan pada tindakan siklus berikutnya yaitu siklus 3 .

Hasil evaluasi tindakan siklus 3 menunjukkan nilai total yang diperoleh siswa adalah 1950 dengan nilai rata-rata siswa mencapai 88,64, jumlah siswa mencapai KKM sebanyak 22 siswa atau $100 \%$ dan telah tidak terdapat siswa yang tidak mencapai ketuntasan. Data tersebut menunjukkan bahwa target $90 \%$ siswa dapat mencapai ketuntasan telah tercapai sehingga tidak diperlukan siklus lanjutan. Prosentase ketuntasan belajar siswa pada tindakan siklus 3 sebesar $100 \%$. Hal tersebut menunjukkan bahwa hasil belajar mata pelajaran Fiqih siswa pada tindakan siklus 3 adalah tinggi. Prosentase ketuntasan belajar siswa sebesar $100 \%$ telah memenuhi target yang ditetapkan yaitu $90 \%$ dari jumlah siswa seluruhnya telah mencapai ketuntasan.

3. Peningkatan Hasil Belajar Mata Pelajaran Fiqih Materi Haji dan Umrah Melalui Penerapan Metode Advokasi Siswa Kelas VIII-2 MTs Darul Ulum Kecamatan Bumi Agung Kecamatan Bumi Agung

Setelah diadakan penelitian yang terdiri dari tiga siklus dan ditempuh dalam 3 kali pertemuan dengan alokasi waktu 6 jam pelajaran diperoleh hasil yang cukup memuaskan. Penerapan metode Advokasi secara nyata dapat meningkatkan aktivitas guru dalam pembelajaran, aktivitas belajar siswa serta hasil belajar Fiqih siswa yang ditandai dengan meningkatnya ketuntasan hasil belajar siswa. Kesimpulan akhir penelitian ini adalah penerapan metode Advokasi dapat meningkatkan hasil belajar mata pelajaran Fiqih siswa kelas VIII-2 MTs Darul Ulum Kecamatan Bumi Agung setiap siklusnya rata-rata 28,79\%.

\section{PENUTUP}

Berdasarkan hasil penelitian yang telah dipaparkan dapat disimpulkan sebagai berikut.

1. Hasil belajar mata pelajaran Fiqih materi pembelajaran Haji dan Umrah siswa sebelum penerapan metode Advokasi di kelas VIII-2 MTs Darul Ulum Kecamatan Bumi Agung Kabupaten Way Kanan adalah sangat rendah yaitu dari 22 siswa hanya terdapat 3 siswa atau 13,64\%, siswa tidak mencapai ketuntasan sebanyak 19 orang atau $86,38 \%$.

2. Hasil belajar mata pelajaran Fiqih materi pembelajaran Haji dan Umrah siswa setelah penerapan metode Advokasi di kelas VIII-2 MTs Darul Ulum Kecamatan Bumi Agung Kabupaten Way Kanan termasuk kategori tinggi atau baik dengan indikator $100 \%$ siswa dapat mencapai ketuntasan setelah tindakan siklus 3.

3. Penerapan metode Advokasi dapat meningkatkan hasil belajar mata pelajaran Fiqih siswa kelas VIII-2 MTs Darul Ulum Kecamatan Bumi Agung Kabupaten Way Kanan dengan indikator:

1) Aktivitas guru dalam pembelajaran termasuk kategori baik yaitu mencapai $95 \%$ pada siklus 3 dimana semula mencapai $72,50 \%$ pada siklus 2, $45 \%$ pada siklus 1 , dan $32,50 \%$ pada tindakan prasiklus.

2) Aktivitas siswa dalam pembelajaran masuk kategori baik yaitu mencapai $93,56 \%$ pada siklus 3 dimana semula $67,42 \%$ pada siklus 2, 46,97 pada siklus 1 dan $28,40 \%$ pada tindakan prasiklus. 
3) Ketuntasan belajar siswa mencapai $100 \%$ dimana semula $13,64 \%$ pada prasiklus, $40,91 \%$ pada siklus 1 , dan $72,73 \%$ pada siklus 2 .

\section{UCAPAN TERIMAKASIH}

Peneliti mengucapkan terima kasih kepada LPPM STKIP Nurul Huda Sukaraja OKU Timur, MTs Darul Ulum Kecamatan Bumi Agung Kabupaten Way Kanan dan Tim Jurnal Al l'tibar Program Studi PAI STKIP Nurul Huda.

\section{DAFTAR PUSTAKA}

Daradjad, Zakiah. 2008. Pengantar IImu Pendidikan Islam. Jakarta: Bulan Bintang.

Thobroni, Muhammad. 2011. Belajar dan Pembelajaran: Pengembangan Wacana dan Praktik Pembelajaran dalam Pembangunan Nasional. Yogyakarta: Ar-Ruz Media.

Slameto. 2010. Belajar dan Faktor-faktor yang Mempengaruhinya. Jakarta: Rineka Cipta.

Utsman, Abdulah. 2013. Dasar-dasar Agama Islam. Jakarta: Kencana Media.

Utsman, Muhammad Uzer. 2011. Upaya Optimalisasi Kegiatan Belajar Mengajar. Bandung: Remaja Rosdakarya.

Huda, Miftahul. 2013. Model-model Pengajaran dan Pembelajaran. Yogyakarta: Pustaka Pelajar.

Hamalik, Oemar. 2010. Proses Belajar Mengajar. Jakarta: Bumi Aksara.

Wena, Made. 2013. Strategi Pembelajaran Inovatif Kontemporer; Suatu Tinjauan Konseptual Operasional. Jakarta: Bumi Aksara.

Djamaluddin, Kamal. 2009. Strategi Belajar Mengajar Melalui Penanaman Konsep Umm dan Konsep Islami. Bandung: Refika Aditama.

Primasari, Ria Triana. 2012. Kecerdasan Emosional dan Belajar. Palembang: Grafika Telindo Press.

Dimyati dan Mudjiono. 2009. Belajar dan Pembelajaran. Jakarta: Raja Grafindo Persada.

Wardhani, Igak. 2008. Penelitian Tindakan Kelas. Jakarta: Universitas Terbuka.

Arikunto, Suharsimi. 2010. Prosedur Penelitian;Suatu Pendekatan Praktik. Jakarta: Rineka Cipta. 